\title{
最近の混練, 分散機について
}

は じめに

混合, 混称り, 練合わせ分散, 分散等固/液懸濁系の 単位操作は粒子を分離, 分裂させ散逸, 散在させる機珹 的方法であるということが出来る。それらの言葉の違い は学会, 業界ばかりでなく, 対象物や粘度, 最終の粒径 オーダー等によって生じているらしい。混合も分離と完 全まぜ合わせを定義するし，混袧りも同様の目的をもっ ている。

分散といらと粒子の分裂, 分離の方に重点がむけられ る。均一混合, 完全混合もその重要な意味をるつのであ るが，分散は水や低粘度液体中に粒子がちらばることよ り解釈されるようである。もともとコロイド化学の面か ら出発したものであるから, 混合, 混祆りとは若千考党 方が異なるように思うのは止むを得ない。

混ねり機, 分散機を解説するにあたり, いつもこの点 で迷う。

混ねり機, 分散機による混ねり, 分散はいずれも強力 な機械的エネルギーで行われるるのであるが, 一般に混 ねり機はニーダーやバンバリーミキサー等を用いて, 超 高粘度系の粒子分散气はかるものであり, 分散機は中粘 度以下の系に和ける分散の目的を達成するものと区別し てよいように思う。ロールミルは相当広範囲の粘度領域 まで適用されるので, 両者の性格をもつものと考えられ る。梅屋氏1)の言葉を借りれば超高粘度系はペンデュラ 一, ファニキュラー（I）（II）の領域で中粘度系はキャ ピラリー域よりスラリー域属する。それ以下といらの は,フローヌまたはフリニイッド域と考学てよい。
新しい混ねり機, 分散機の開発は新しい混ねり, 分散 機構が研究されないと仲々進まないるのである。ボール ミル，ロールやニーダーは戦前よりあったが，メジアを 用いて行ら分散機構は戦後開発され, サンドミルに代表 される。それ以前よりボールミルのボールを小さくし， 堅型槽にしてアジテーターで分散しょうという考光方は あったが，広く実用化されたのはサンドミルである。そ れ以来 25 年は経過している。

新機構による分散機がなかなか開発されないのは, 色 々の制約条件があるからである。たとえば色替方や掃除 が簡単に出来るとか, もっと吐出量をあげるとか, 完全 密閉にしてしかる発熱しないようにするとか等であり, 何といっても, 単位動力当たりの分散度をあげることに 重点が特かれる。しかし粗粒子の分裂, 分散といらプロ セスはさまざまな挙動を示し，それがずで表面化学や コロイド化学の対象になることから，そういら関係技術 者の要求もますますエスカレートするからであろう。

以上のようなことを念頭に置いて, 最近の傾向を紹介 したい。

\section{1. 混ねり機, 分散機の種類について}

混ねり機, 分散機を分類する方法は色々あるが, 大抵 構造上から分類されている。塗料, 印刷インキ等の色材 工業では構造上の他に機能的に分けてみることと, 用い る粘度䉇囲が $10^{10} \sim 10^{0}$ ポイズといらことであるから， この面からも考光なければならない。

構造上からは次のように洘完られる。

（1）ベッセル，またはタンクの状態にもとづくもの

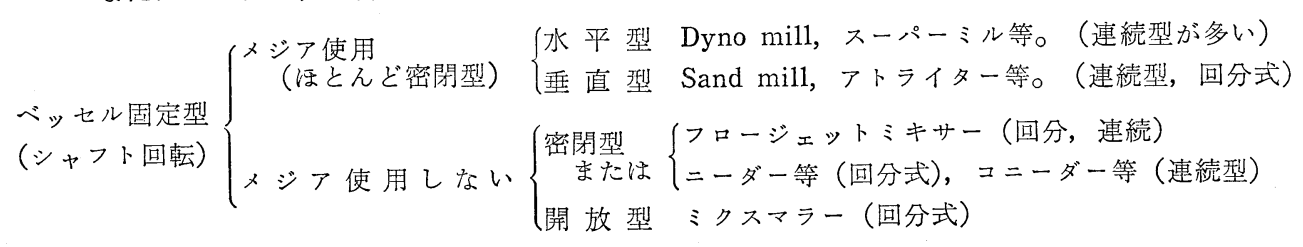

昭和 52.11.9 受理

On the Recent Grinding and Dispersing Devices Taiithi TSURITANI
* 埼玉県北本市北本宿 68-41 釣谷技術士專務所 


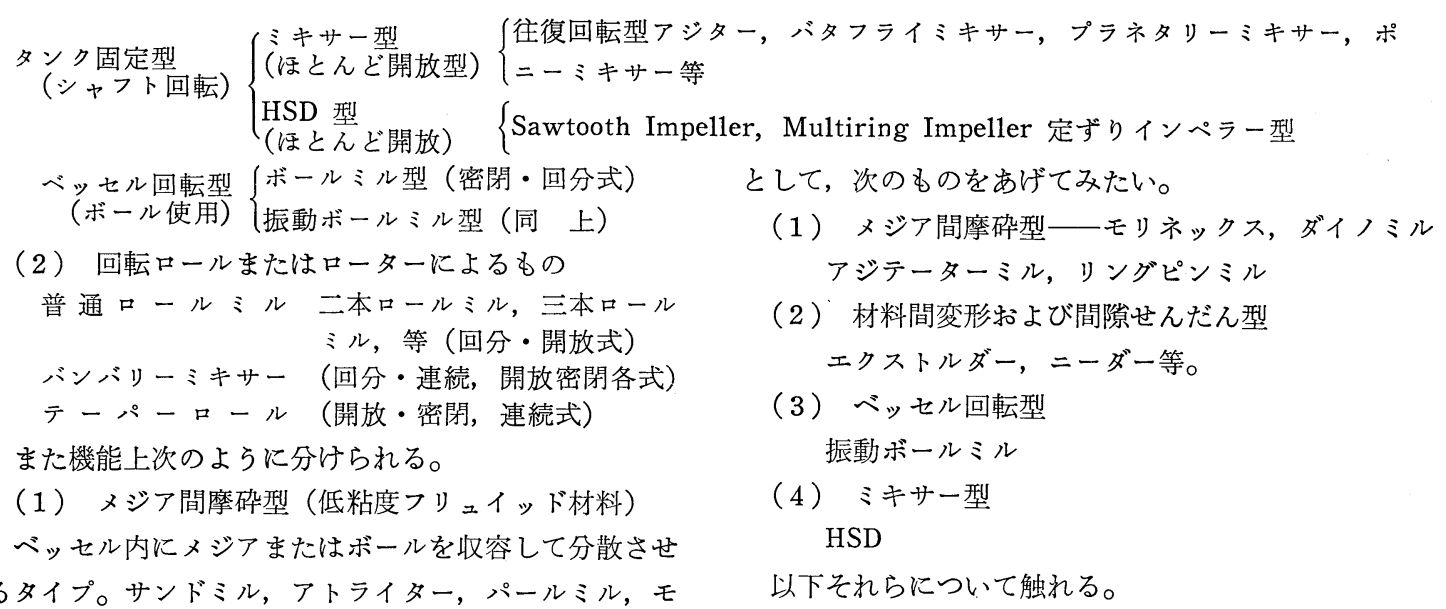

\section{2. メジア間摩砕型}

ル,アジテーターミル, 堅型ボールミル等

（3）間隙通過型（各種粘度系材料）

ロールミル，コロイドミル，フローミキサー，バンバ リーミキサー等

（3）材料間せんだん変形十間隙せんだん型（超高粘 度材料)

ニーダー，コニーダー，エクストルーダー，バンバリ 一ミキサー等

（4）ペルセル回転型（低粘度材料）

水平型ボールミル, 振動ボールミル等。

（5）ミキサー型（各種粘度系材料）

$\mathrm{HSD}$, 各種混合カクハン機。

（6）瞬間混合せんだん型（低粘度材料）

フロージェットミキサー等。

以上のように分類される。これらには単に混合だけの 働きしかないものも含まれている。（）内の材料は混合， 分散したものの系について記してある。

従って, その系の粘度はせんだん力等の外力の作用し ている機内の粘度と吐出または取り出した粘度両方を含 んでいるが，一般に材料同志のせんだん，ねじり，引張 り, 圧縮等の変形を利用するニーダーを除いて，固/液 懸濁系の場合，その機械の混合分散機構に応じ，最も適 切な粘度が存在する。すなわち最大最良の分散度を得 て, 最大の吐出量をらるためには最も適切な粘度が必要 である。固/液懸濁系の場合，粘度を左右するものは粉 体量とビヒクルまたはバインダーあるいは固形樹脂量で あるから，その機械にかける場合のフォミュラが最適で あることが必要である。従って粉体の種類やバィンダー の種類にも影響し, 事前にそのような材料の特性をは握 しておくことが重要な事前準備といえよう。

今回のテーマは最近の混齐り, 分散機であるから候補

この型の分散機は塗料, グラビヤインキその他低粘度 流動体の分散に用いられ, 堅型, 密閉連続式が従来の主 流であった。モリネックス,リングピンミルはいずれも 堅型であるが，ダイノミル，スーパーミル，アジテータ ーミルは横型である。そこで, まず堅型か, 横型かの議 論が出ようと思うので，この面から考光てみたい。

（1）堅型ミルと横型ミルの長所，欠点

同じ容量のベッセルで, 同じ形のディスクをつけたシ ヤフトで,メジアを $60 \%$ 容量程入れて, 1,200 rpm で 回転したとし，同一塗料を通した場合，同一分散度を得 るためには何時間かかるか，こらいら問題の解答はその まま，堅型と横型の比較が出来るということである。

分散可能かどらかはメジア層の最大せんだん力の大き さ, 作用域, ヘッャル全体のせんだん力の分布がきめ手 になる。

サンドミルについてはディスク間およびディスクの円 周方向にせんだん作用があり, 最大せんだん力はメジア の空間率に依存し，一区間のデスク間ではそのオーダー は $10^{4} \sim 10^{5} \mathrm{dyne} / \mathrm{cm}^{2}$ の応力であるから, 顔料粒子の硬 さによって，分散不十分なものもあることが分る2゙。 た作用域もディスクの周辺のみで, ディスク間の中央や ベッセルの壁では非常に弱く, かつベッセルの高さ方向 にせんだん応力の分布のあることも説明した2)。底 部と 上部ではあまり分散に寄与しないといらことである22。

横型はどらであろらか。最大せんだん力は堅型のdう な大きさではない代りに, 堅型は遠心沈降方向のせんだ ん応力とベッセ高さ方向の垂直応力の和と考える。作 用域やせんだん応力の分布はベッセル全体にわたって， 堅型汪ど不均一ではなからう。これらの因子はメジアの 量, $\mathrm{rpm}$ ディスク間々吵の大きさに大に影響すると考 
えられる。従ってベッセル全体の温度分布は堅型の不均 一さに比べ, 比較的均一であろうから, 温度による内部 材料の粘度低下は入口より出口まで, 大体均一であろう と思われる。

従って, 壁やディスのの摩耗も, 全体にわたってかた よりは少なくなる。若し最大のせんだん応力が堅型に等 しいか, 堅型よりも大きい場合は堅型より分散能力はす ぐれているといえる。また分散エネルギーを $E$ とし，せ んだん応力を $\bar{\sigma}_{s}$ ，そしてベッセル円筒面積を $A$, 長さを $l$ とすれば $\bar{\sigma}_{s}=f(l)$

$$
E=A \int_{0}^{l} \bar{\sigma}_{s} d l=A \int_{0}^{l} f(l) d l
$$

が横型の方が大きいと竪型よりも有利にならう。

横型で問題になるのはメジアと液の分離である。特許 にみられる要点はおるにこの点である。

（2）横型サンドミル

ダイノミル(Dyno mill) $)^{3}$,アジテーターミル (Agitator mill with micro balls)4) アジテーションビーズ, パー ルミル (Agitation beads-pearl mill) ${ }^{5}$ )およびスーパー ミル (Super mill) $\left.{ }^{6}\right)$ はいずれも横型サンドミルである。 ダイノミル, アジテーターミル, スーパーミルの図を次 に示す (図-1)。

横型サンドミルは重力による垂直応力が堅型サンドミ ルのそれに比べ，無視しても差しさわりはない。従って 遠心沈降によるせんだん応力を考光ればよい。さてディ スク間の砂の速度分布は堅型サンドミルと同様に考学れ ば，放物線であるから砂の速度 (半径方向)を $v_{r}$, 時間 を $t$ とすると， $v_{r} t$ の距離分布となる。ここでシャフト の軸方向を $x$ ，ディスク間距離を $H$ とすれば,

$$
r=v_{r} t(x)=-\left(a x^{2}+b x+c\right)
$$

のパターンとなる。練合分散エネルギー $E$ は $(\gamma-c)$ を 原点とした場合

$$
E_{1}=\sigma_{\max }\left[\pi \int_{0}^{H / 2}\left\{v_{r} t(x)\right\}^{2} d x-V_{s}\right]
$$

$\left(\bar{\sigma}_{s}=\sigma_{\max } / 2, \quad V_{s}\right.$ は単位区間当たりのシャフトの容積 である。)

だけ消費することになる。これを単位時間で割れば消費 エネルギー逸散速度が求まることになる。

次に, シャフトの回転によって強力に作用する容積は ディスクの数を $n$ とすると

$$
V_{a}=n \pi \int_{0}^{H}\left\{v_{r} t(x)\right\}^{2} d x
$$

これがベッセルの容積 $V_{T}$ に占める比率

$$
V_{a} / V_{T}=R(\%)
$$

は有効作用率である。1ディスク間ではパターンから考 えて $R=60 \sim 70 \%$ 程度であらう。これは垂直型サンド

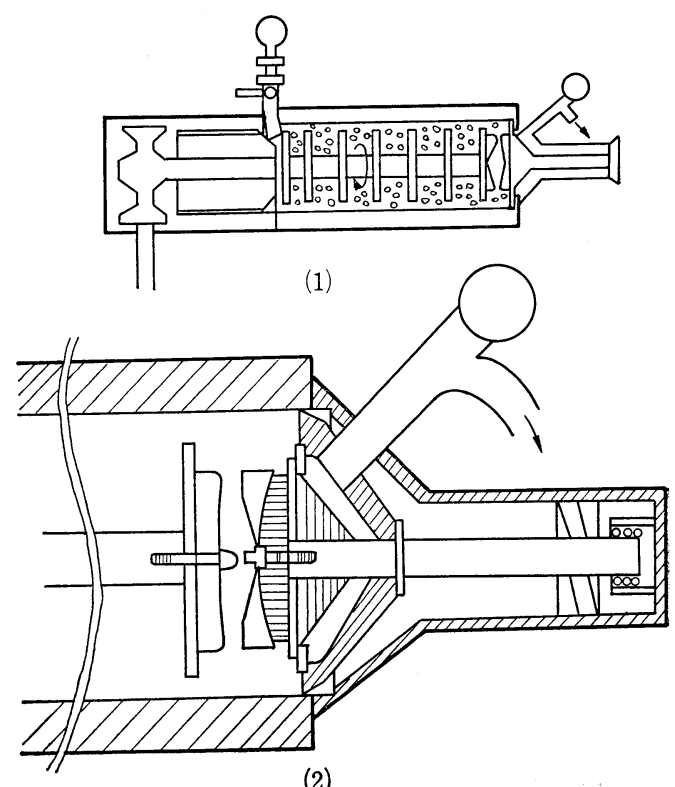

(2)

図-1・1 ダイノミル（1）全体図（2）分離部 ${ }^{3)}$

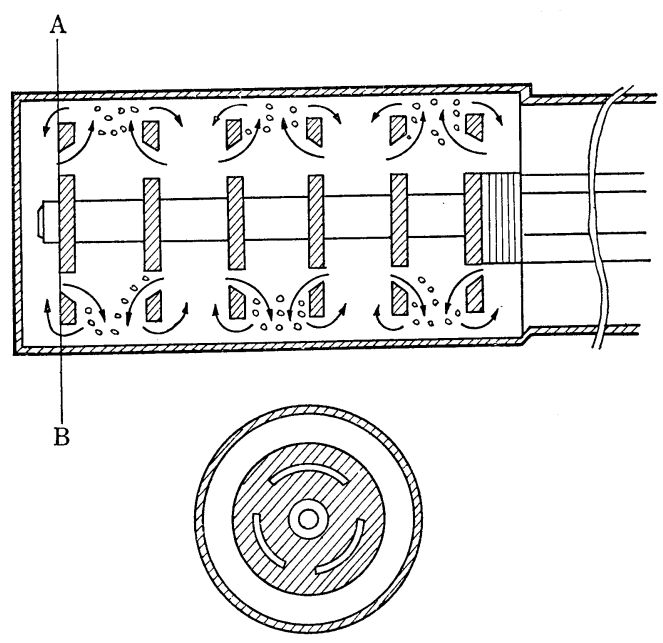

図-1・2 スーパーミル6)

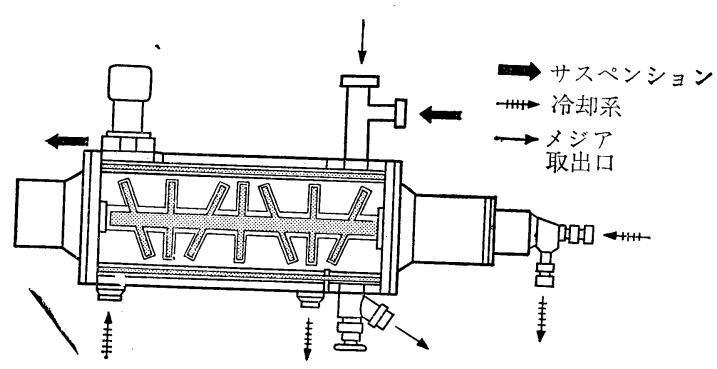

図-1・3 アジテーターミル4 
ミルに比して，大きいと思われる。

次に考慮すべき問題はペッセル内砂充てん密度の变化 である。

堅型の場合, 密閉型ではベッセル長さ方向のせんだん 応力分布に一椂に圧力がかかる。砂の空間密度変化はボ トム注ど密でトップほど蹯であることに変りはない2)。 また液の上昇速度が大きいと砂と液の分離が困難となり 閉塞する原因となる。横型の場合粗分散液が入口方向に 入り，その圧力が砂に作用しわずかずつであるが出口方 向に移動する。精分散液は Gap separation の場合わず かの間隙より出るので, 出口の方に砂がかたより, 充て ん密度は増加しよう。その場合軽いメジアほどその傾向 は大きい。これを解決することが，この型のミルのポイ ントであろう。

ダイノミルはシャフトに固定している羽根（切込及が ある）とこれと対をなすフリーの回転を行うシャフトに とりつけた羽根によって調整しているように考兄られ， スーパーミルはディスクに穴をあけ，砂の隣のチャンバ 一への移動を可能にすると共に，スクリーン分離をして 、いるところに特徴がある。Gap separation は Screen separation に比べ，圧力上昇は大きいと考觉られる。ア ジテーターミルは垂直と斜方向のディスクが交互にシャ フトにとりつけてあり, 砂のかたより防止と分散効率の 上昇を脪らっている。この場合の砂の運動は複雑であ る。また，同じアジテーターミルで低速度用として， “John System”の Pin Agitator むある。これは竪型 ああり, 後述する。

メジアと液の分離方式は上述した Gap separation と Screen separation があるが，同じ Gap separation では あるが, アジテーターミルは vibration ringslot separationを採用している。

用いられるメジアは分散系の種類と粘度を考慮して, separation clearance より大きいものであれば何でも使 用出来るが，分散効果和よびシャフトの回転数を考兄る とボールミル球のメジアは使用してもあまり意味はな い。

メジアの充てん率は堅型より横型の方が余計収容出来 るので，その分だけ分散効率は大きくなるかもしれな い。このことはメジアの充てん密度分布（せんだん応力 分布), メジアと液の運動, 分離機構等から考兄て納得 出来る。

ディスクの配列, 間隔, ベッセルとディスクのそれぞ れの半径比, 個数, 形状はそれぞれ特徴のあることは図 より分る。一番大切なことは間隔であろう。最も適切な 間隔はシャフトの回転数と系の粘度に関係する。
次に発熟による温度上昇であるが，ベッセル外筒，シ ヤフトにそれぞれ冷却水が通っているので, 堅型（シャ フトに冷却機構のないもの）飞比べ，一般に少ない。温 度の上昇度を $\Delta T$ とすれば， $\Delta T$ は次の因子に関係す る。

$$
\Delta T=f(\eta \cdot T \cdot \text { 有効作業率 })
$$

\section{$(\eta:$ 粘度, $T:$ :ルク $)$}

$\Delta T$ は出口側の泠却水温度によって, 内部温度の $\Delta T$ が推測されるが, 内部の $\Delta T$ の大小は冷却機構のみによ って，きまると考光られる。

堅型サンドミルは系の粘度によるメジフの充てん密度 の低下やクッション浮上機構2)が問題になるが，横型で は堅型に比べ少ないように思われる。それはメジアの充 てん率が堅型に比べ，多いことによるものといえよう。

分散度と吐出量との関係であるが，図-2 のようなデ 一タがあるので，参考までに揭げて拈く7。またこのデ 一タに用いられた適用粘度範围は $5 \mathrm{P} \sim 80 \mathrm{P}$ までであっ た。なお用いられている色は青, 赤, 白, 黒, グレー等 各色である。この図より判断する限り, 竪型サンドミル と大差はないが，同一容量のそれと比較したわけではな いので，その点コメント出来ない。

(3) モリネックス8), リングピンミル9)

両者とも堅型ミルで, モリネックス (Molinex) はエ キセントリックリング回転によって分散効率をあげよう といらもので, 最近のものは内部も冷却出来るようにな っているから, 以前のような温度の上昇をセーブ出来 る。このタイプはディスクの代りにリングを用いている 点にあるが，リングはシャフトに $120^{\circ}$ の間隔でとりつ けられ，かつ㹂方向に図-3のような配列をして扣り，一

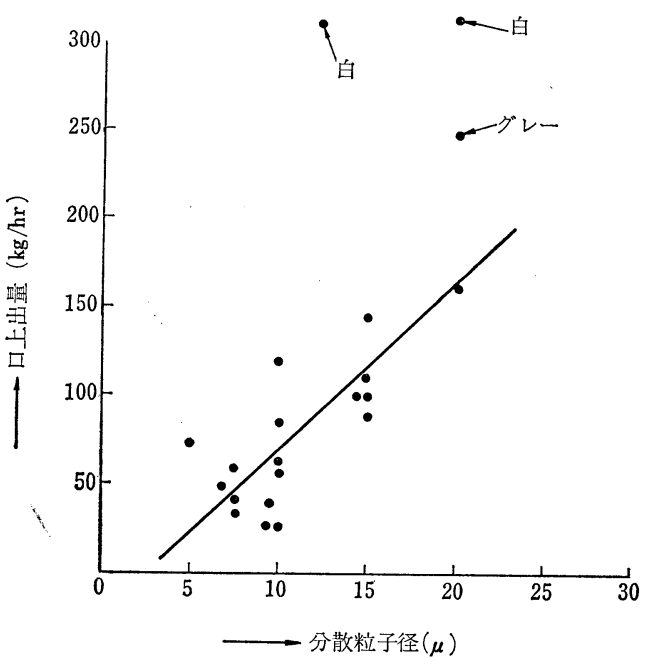

図-2アアウトプットと分散度》) 


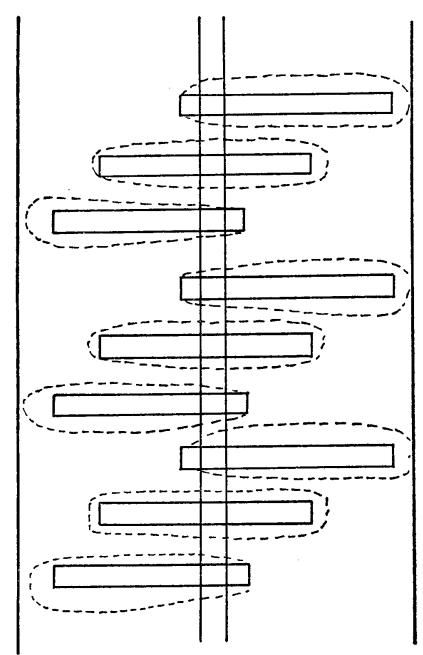

図-3・1. モリネックスリングの配列 ${ }^{8)}$

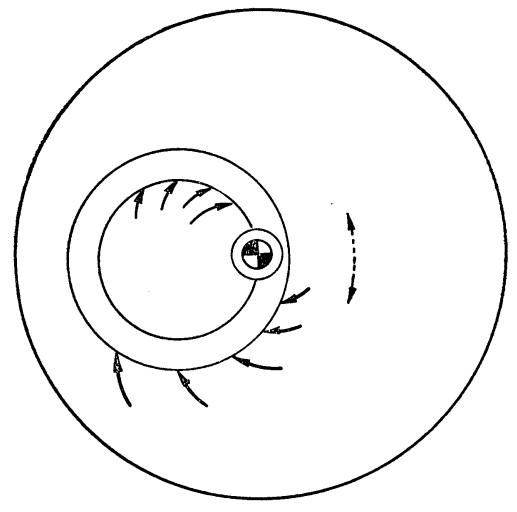

図-3·2 モリネックスのリング

つのリングが $240^{\circ}$ の角度を回転すると次のリングがく るようにしてある。r.p.mは 900 r. p. m であり,メジア へのインパクトやせんだんが間断なく進行するよらエキ セントリックに回転するから, 非作用域はタテ型ディス クタイプに比へ，非常に少ない。またメジアの充てん密 度は重力効果により, ディスク型より密で, 六方充てん ないし最密充てんをとりらる。この充てん型式はディス ク型が回転中に空隙率 50〜60\% になるに比べ，30〜 40 \%と小さくなるから，パッキング効果はモリネックの方 が大きい。こういらことから中高粘度も可能とい党る。 メジアの充てん密度が大きいことから，それだけトルク も大きくなるのではないかと考光られるが，それほどで るない。ただ粘度が大きくなると, 充てん密度の増大と 共に発熱量は他のサンドミルに比べ大きいので泠却の必 要が出てくる。最近のものは, そのような機構を備えて いるようである。

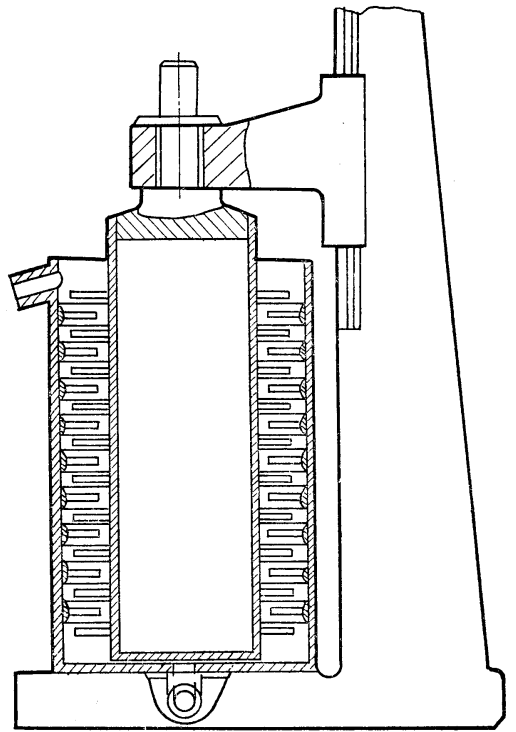

図-4 リングピンミル (Netzsch 社 ドイッ特許 $1233237^{9}$ )

リングの運動機構は図-3 のようにメジアがリングに まきこまれると共に, リング周辺にメジア間のせんだん 力が働さ分散能力が発揮される。この場合の立体的なせ

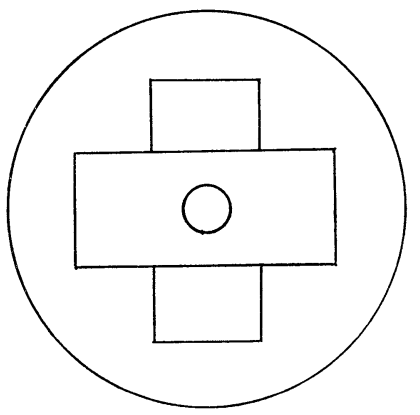

図-5・1 ロータサーシル（水平断面図）

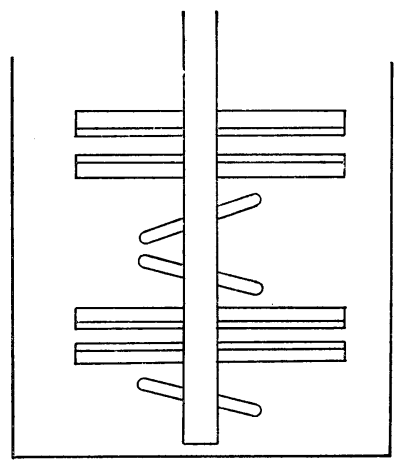

図-5.1 Sweco's ロータリーミル(垂直断面図) 


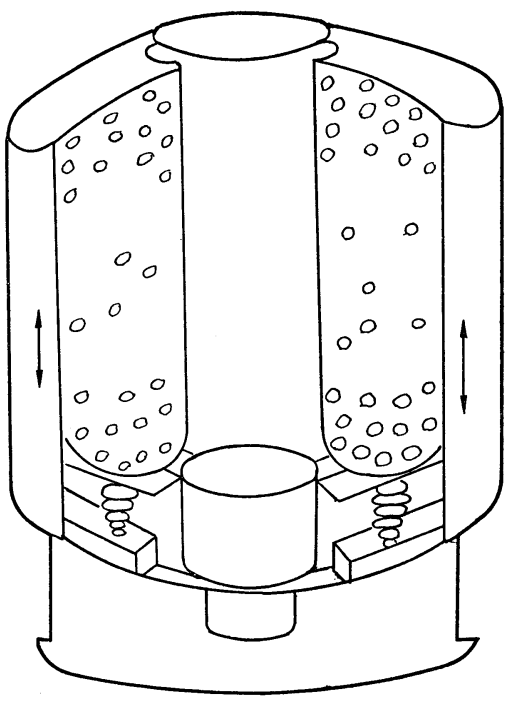

図-6・2 Sweco's 振動式湿式ミル10)

\section{んだん応力分布は複雑である。}

リングピンミル (Ring pin mill) は “John System” といわれているが，模型もある。これはシャフトとべッ セル壁にロッドを交互になるようとりつけられ、シャフ トに取付けたロッドが回転すると、ロッド間にメジアの せんだん作用が働くようになっている。このタイプはパ ールミルやアトライターのロッドがせんだん作用を行う 作用域よりるべッセル全体の割合からみると, はるが 大きくなっている。それは図-4 より分ると思うが，丁 度ロッドのせんだん作用方向が互いに逆になっているこ とから，低速でもかなりの分散効果が期待出来る。

Sweco rotary grinder ${ }^{10)}$ は図-5 のよらなインペラ 一を用いているが，アトライター (attritor)のロッドを もっと大きくしたタイプと考兄られる。同じ Sweco 社 の Vibratory wet Grinding ${ }^{10)}$ は図-6に示すような 20 hertz 程度の振動周期を与えて, ハードな材料の破砕に
用いられる。

その他, 堅型ボールミルもまた興味があり, 研究報告 が出されている11)。

\section{3. 材料間変形, 間隙せんだん型一ねつ和機}

このタイプは高粘度, 超高粘度材料への顔料の分散に 用いられ，ニーダー，エクストルダーに代表されるグル ープである。今までの摩砕型は低粘度ミルで高粘度では 歯がたたない。

この種一連の練合分散技術は粉体塗料, 硬ねりべー ス, ゴム, フラッシュ技術や顔料製造等色材工業に扔い て重要な地位を占めつつある。特にエクストルダーは, 粉体塗料の製造にはなくてはならないものとなってい る。

これらのねつ和機 (Kneading Machine) は決して新 しいものではなく, 以前より存在していたが，特にニー ダーについてはな持未解析の点が多い。

(1) $=$ ーダー (Kneader)

ニーダーに必要な条件というのは表-1 のようである。

このらち何といっても, 最も重要なことは粉体, バィ ンダーの種類によって, 所望の分散混合度を得るために はこの方法でよいかぞらかの判断である。同時に分散混 合度をどの程度までにするかの目標である。と同時に何 時間かかるかといら問題もある。これらの問いに対し， 適確に答えるためにはニーディング機構を知る必要があ る。

ニーダーの練合分散作用は，一つは材料間のせんだ ん, 引張, 折たたみ, 圧縮, ねじり, まげという力学的 特性がすべて入っていること, 二つは翼間, ベッセル〜 翼間のせんだん力である。前者の力学的パターンは目下 のところ解析の手段がないといってよい。後者は算出出 来る ${ }^{12)}$ 。

これは間隙の流動パターンをレオロジー的に解析すれ

表-1. ニーダー選定上の留意事項

\begin{tabular}{|c|c|c|}
\hline 設計上必要な条件 & 操作上必要な条件 & 機能判定のための特数 \\
\hline $\begin{array}{l}\text { (1) 材料の硬さと翼の回転数 } \\
\text { (2) ベッセル壁と翼の間隙 } \\
\text { (3) 有効な作用域 } \\
\text { (4) 材料が繰返し循環する機構 } \\
\text { (5) 強力なっつ和ェネルギ- } \\
\text { (6) 作業性の容易さ } \\
\text { (7) 放つ和混合パターン } \\
\text { (8) 翼の種類および大きさと容積 } \\
\text { (9) 所要馬力数 }\end{array}$ & $\begin{array}{l}\text { (1) 単位時閒当たりの分散度, 混 } \\
\text { 合度の向上 } \\
\text { (2) 運転, 停止取出のルーチン化 } \\
\text { (3) ガス粉じんの除去 } \\
\text { (4) 安全装置, 安全作業の確認 }\end{array}$ & $\begin{array}{l}\text { (1) 分散特性 } \\
\text { (2) 混合特性 } \\
\text { (3) 㡒環時間特性 } \\
\text { (4) 松つ和力 (応力) エネルギー } \\
\text { の算出 } \\
\text { (5) スケールアップ則 } \\
\text { (6) 材料の状態性質の变化 } \\
\text { (7) 所要馬力数 }\end{array}$ \\
\hline
\end{tabular}




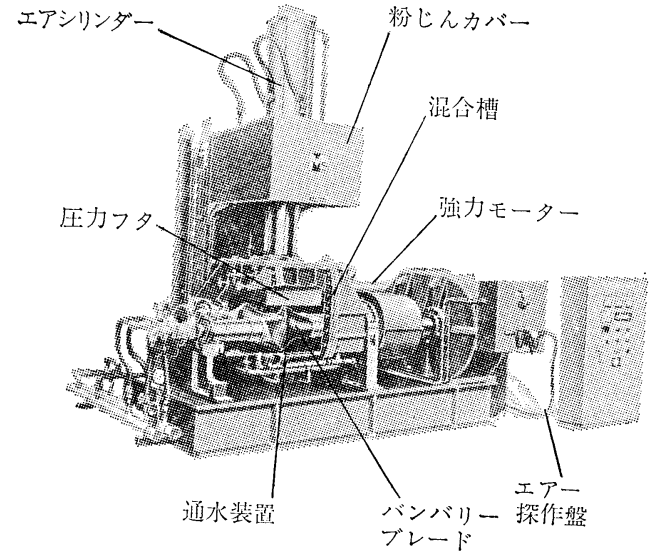

図-7 バンバリーブレードを用いたニーダー

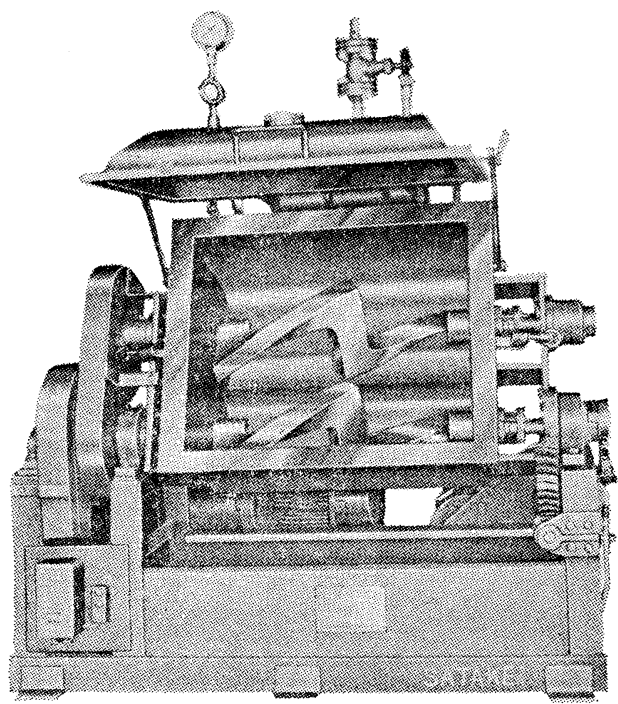

図-8Ｚ型ブレードを用いたニーダー

ば得られこれよりトルクTを計算する。

$$
T=\varphi R^{2} L \tau
$$

ここに $\varphi$ は翼の作用角度範囲, $R$ はベッセルの半径,

Lは長さ， $\tau$ は間吵のせんだん応力である。これよりこ 一ダーの所要動力 IP が計算される。

$$
\mathrm{P}=\psi\left(1+\frac{\alpha}{100}\right)(2 \pi R N)^{2} \frac{R L \mu}{75 C}
$$

( $\alpha$ : モーター効率, $N$ : 回転数, $\mu$ : 粘度, $C$ : 間隙)

ニーダーには回分式と連続式があり, 前者は翼の形に よって, 权つ和能力が異なり，後者はコニーダーにみる ようにスクリュー式が主流である。

ニーダーの中で強力加圧ニーダーは, ゴム等の粘度無 限大の固形バインダーに粉体を混㸚りしたり，ロジン変 性フェノール固形樹脂中に粉体を混福り分散したりする

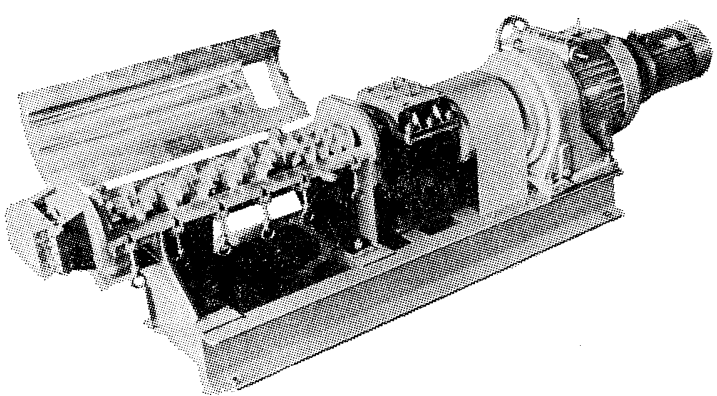

図-9.1コニーダ ${ }^{13)}$
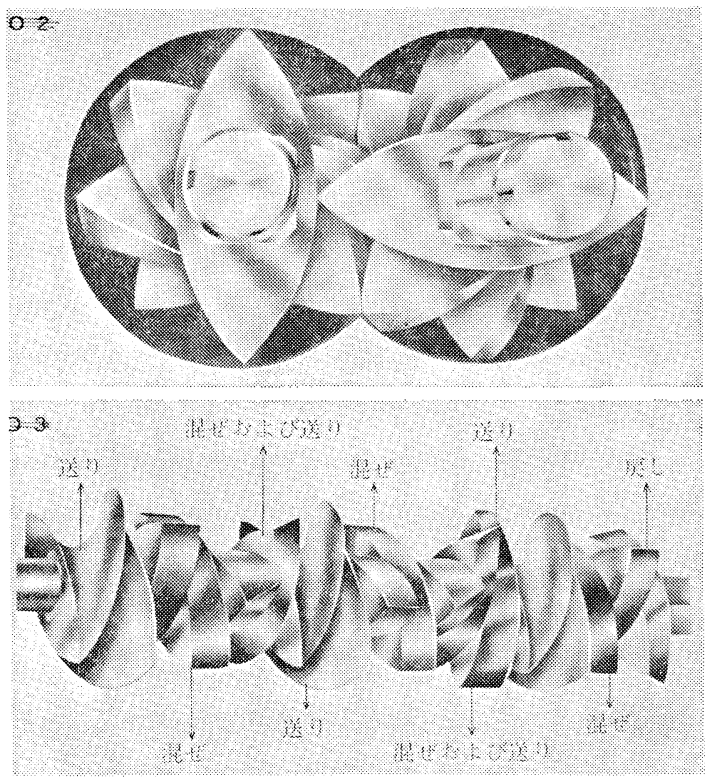

図-9.2 コニーダーのパドル13)

際加圧下のもとに翼が回転するから, 仕込容量によって も変るが $1 \mathrm{t}$ の混合材料飞対し， $70 \mathrm{P} \sim 100 \mathrm{P}$ の動力を 必要とする。従って翼も $\Sigma$ 形, $Z$ 形でなく, バンバリー 型（マスチケータ型）を用いる。代表的例を写真で示す （図-7, -8)。

コニーダーは次の例に示すように, 横型密閉式二つ割 トラフ中に 2 本のかきまぜ軸を並べ，送り込み用スクリ ニーとパドルをつけたのもがある。大きなるのになると パドル径 $508 \mathrm{~mm}$, トラフ長さ $3,700 \mathrm{~mm}$, r. p. m. 45, 所要動力 $300 \mathrm{~kW}$ というものもある。連続式ニーダーは 各社, 各様のものがあるが, 本例は $\mathrm{K}$ 社製13)のもので有 名である（図-9）。

（2）エクストルダー (Extruder)

エクストルダーは昐体塗料の製造に用いられている。 エクストルダーの混ねり機構は比較的よく解明されてお り, 熱可ソ性樹脂加工に和仍る押出成形分るいは射出成 
表-2

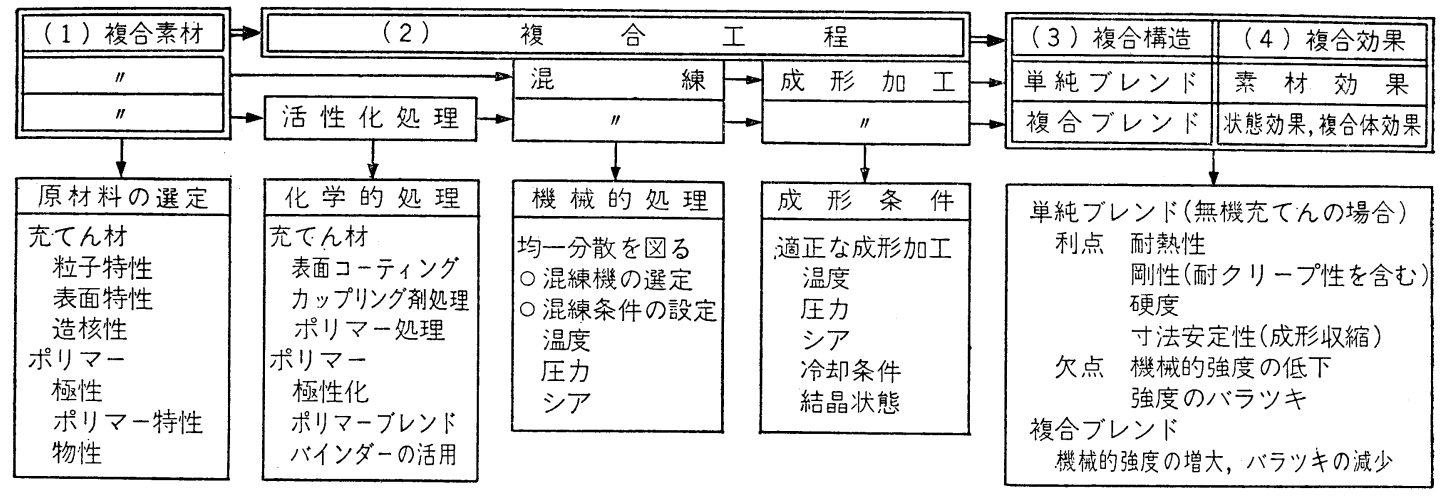

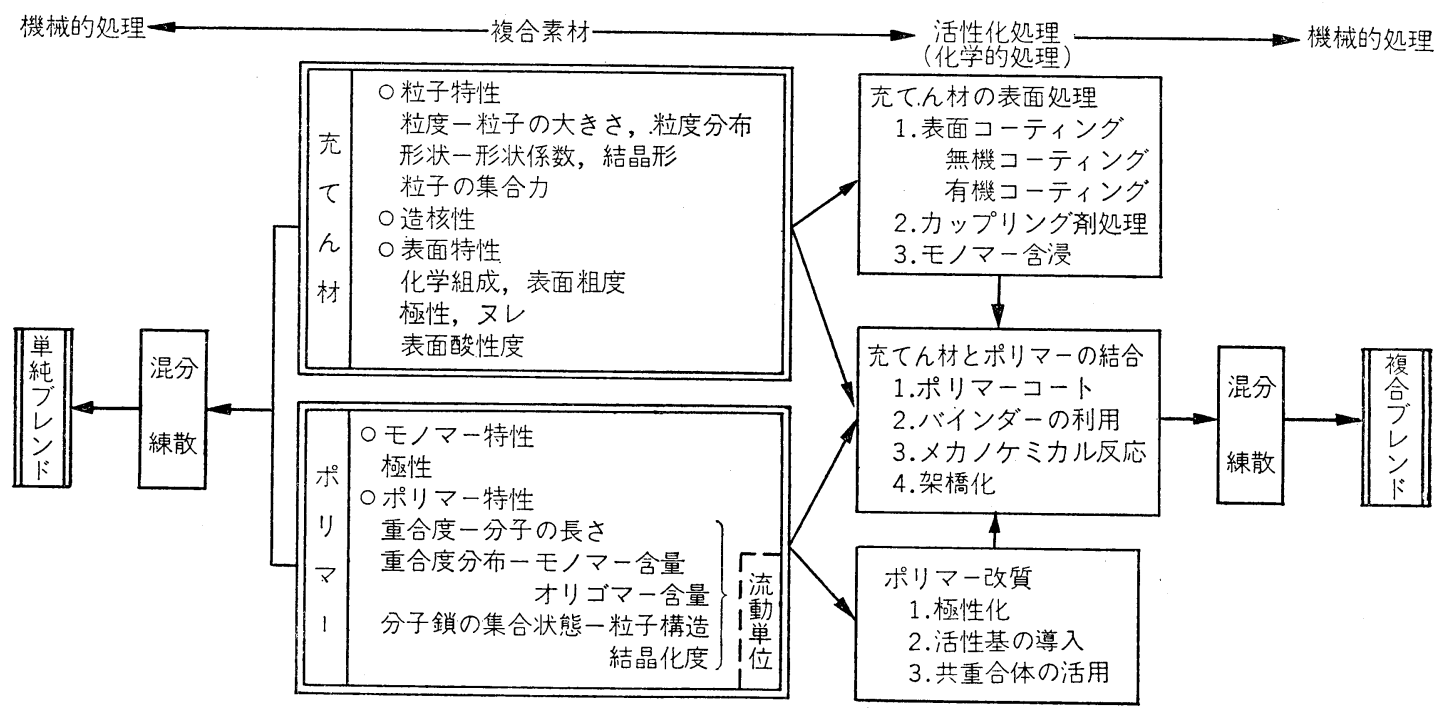

型機で金型を除いたものと考えればよく，一般にスクリ ウ式になっており, これも一軸と二軸, 多軸があるし, スクリューもフルフライトスクリウ，トーピードスクリ ウ，シングルスクリウ等のスクリウの種類がある。
溝の深さ, ピッチの長さによって, スクリウも種々か えられる。あるいはニステージスクリウやテーパー形で、 あったりするのは押出量, 圧力変動, せんだん強さ等を: 適切にするためである。エクストルダーは加温するので

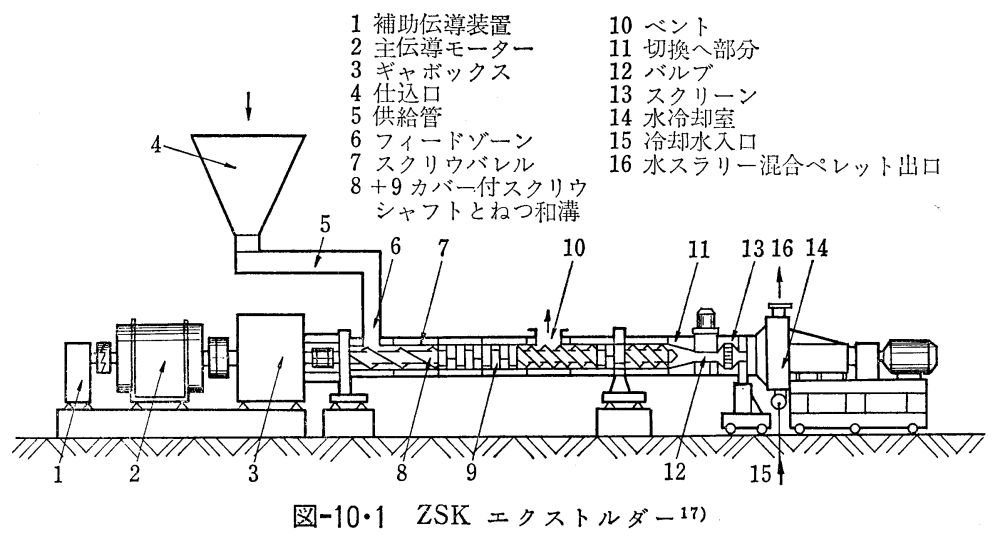

$26[5]$ 

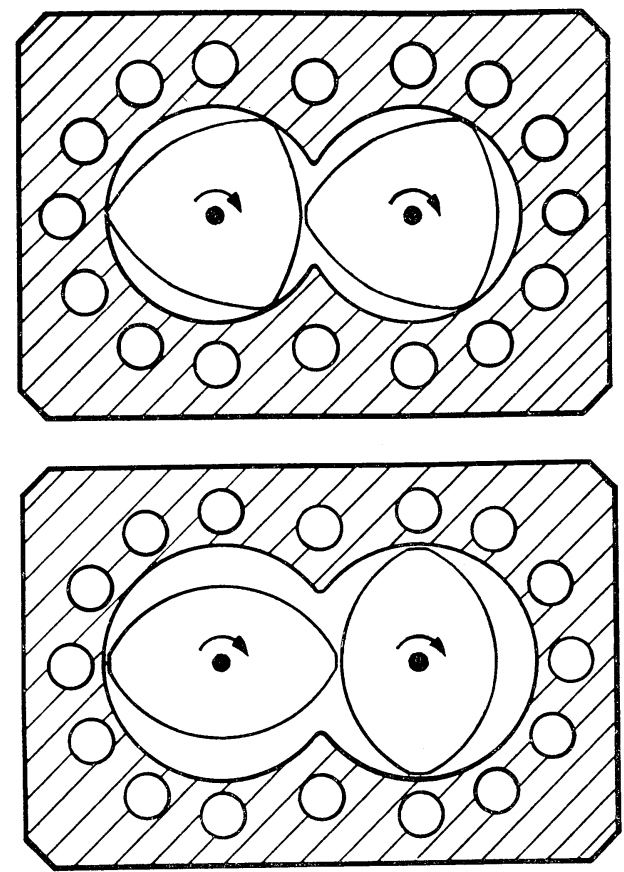

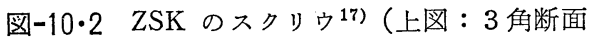
スクリウ, 下図：棈円断面スクリウ）

温度調節が重要である。加熱方式としては誘導加熱方 式, 熱媒体方式があり， $150 \sim 250^{\circ} \mathrm{C}$ の温度制御域があ ると同時に，押出压力は $300 〜 500 \mathrm{~kg} / \mathrm{cm}^{2}$ といらオー ダーになる。

エクストルダーの特徵は普通次のようにいわれてい $ろ^{14)}$ 。

(1) 流動と動力との関係 $Q=\alpha N-\frac{\beta}{\mu}\left(\frac{d p}{d z}\right)$
全流量 $Q=Q_{D}-Q_{P}-Q_{L}$

等温流動 $Q=A N-\beta\left(\frac{\Delta P}{\mu}\right)$

断熱流動 $Q=\alpha N-\left(\frac{\varepsilon \beta}{C}\right)\left(\frac{N^{2} \Delta P}{Q \Delta T}\right)$

(2) 混ねり特性

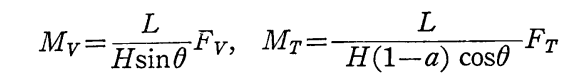

(3) サージング量 $\left[\frac{1}{\Delta Q} \frac{d Q_{0}(t)}{d t}\right]$

(4) 流動特性に対する考慮

Bingham 体, Rabinowitsh 体

Ostwald 体について

$Q$ : 押出流量 $\left[L^{3} / T\right], N$ : スクリウ $\mathrm{rpm}, \mu:$ 粘度 (見掛け), $Q_{D}, Q_{P}, Q_{L}$ : drag flow, pressure flow, leakage flow を示す。 $P$ : 压力, $C$ : 流体の比熱, $M_{V}$ : スクリウみぞ方向のせんたく変形量, $M_{T}$ : 横断 面内のせんだん変形量, $L$ : 軸方向スクリウ溶融部の 長さ, $\theta:$ ヘリカル角, $F_{V}, F_{T}:$ みぞ梁さの関数

これらの詳細については，それぞれ原報告 ${ }^{15)}$ や関係 書 $^{15) を}$ を参考にされたい。ここでは, 詳しいことは省略す る。混㸚り分散について，考慮すべき事項を表-2 に提 げる16)。

エクストルダーの代表例として，ZSK（Zwei-Schnecken Kneter) ${ }^{17)}$ は二軸スクリウ型混ねり機である。 FCM (Farrel Continuous Mixer), CIM (Continuous Intensive Mixer) 他 Kesterman, Schloemann, Cincinati-Milacron, Krauss Maffei, GKN 等が知られて いる ${ }^{18)}$ 。

ZSK は図-10 に見られるようにニーディングと輸送 用のエレメントが色々かえられるようになっている。ま

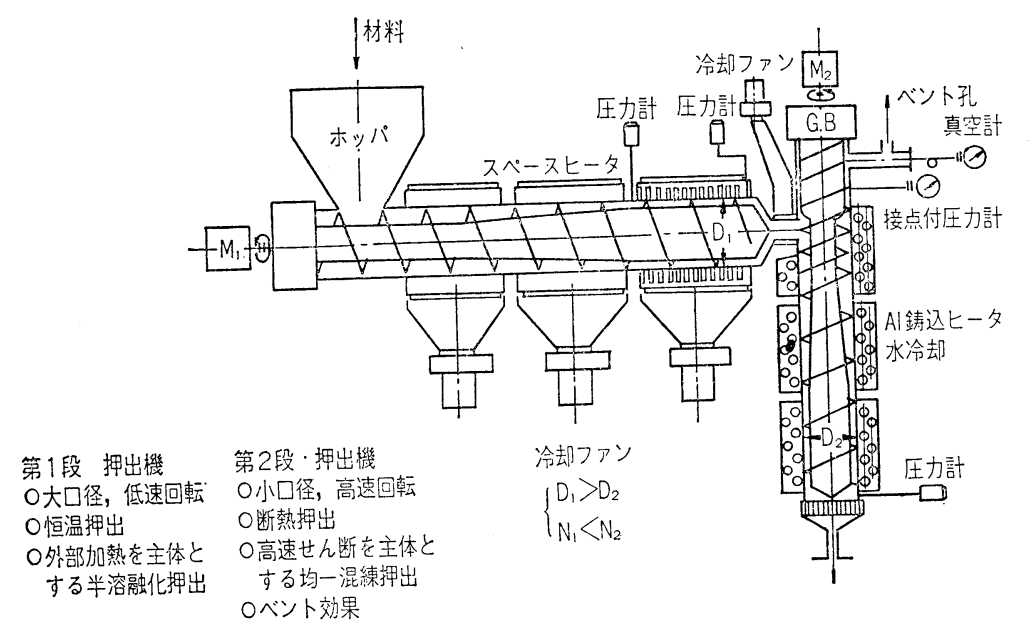

図-11 Twostage processing ${ }^{18)}$ 異径 2 段スクリ二押出機 


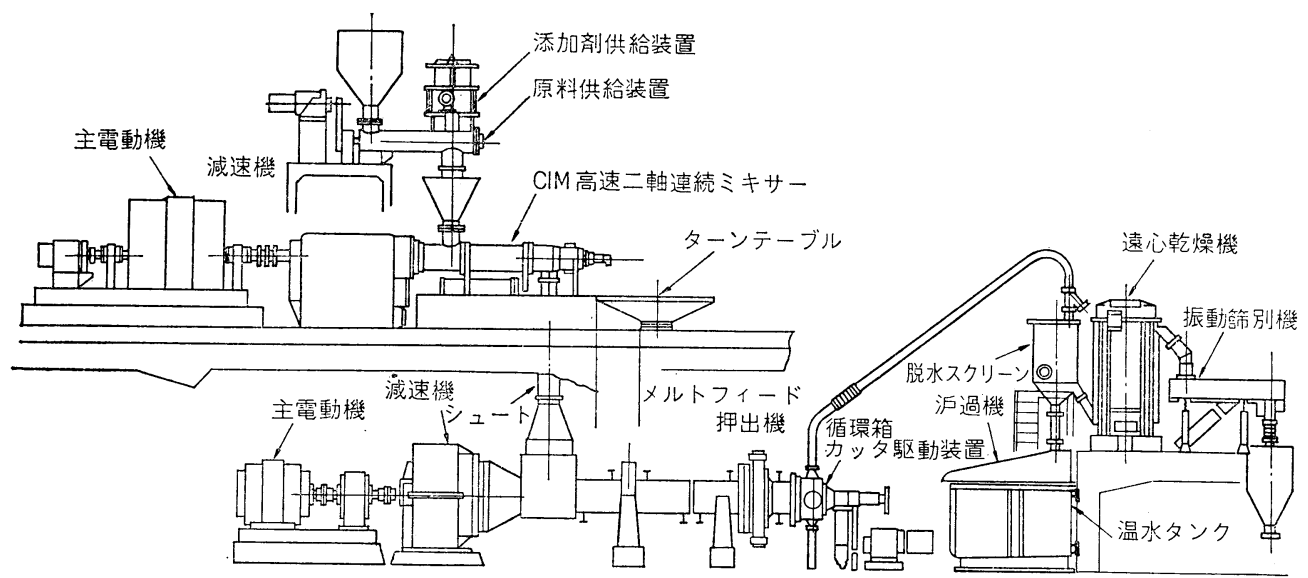

图-12 CIM 高速 2 軸連続ミキサー系列造粒機フローシート18)

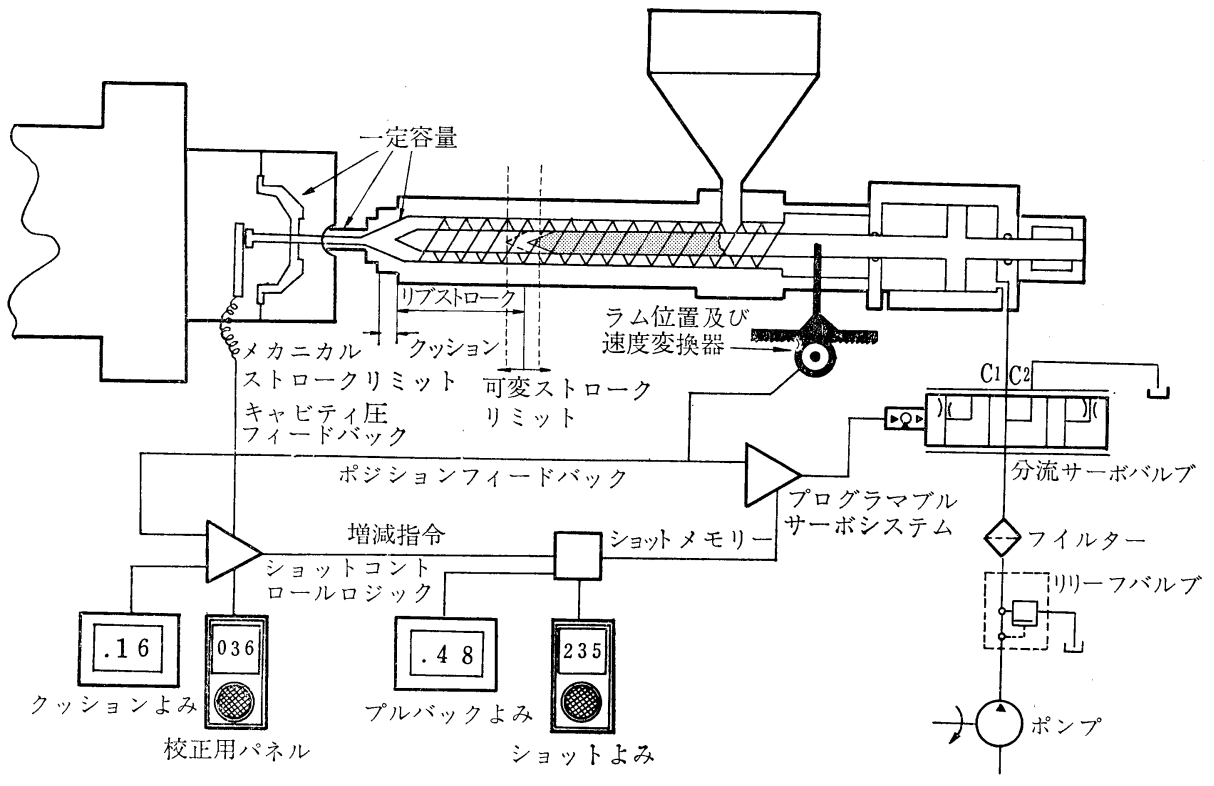

图-13 射出制御機啨19)

たスクリウのかみ合せで，図のよらな二種類がある。用 途として compounding, degassing, homoginizing, masterbatch, reinforcing with glass flbres, condensing 等があげられている。製品としては powder, melt, pellet, masterbatch 何でもござれというところ である。

two stage processing としては一段目で圧縮と外部 加熱, 二段目で断熱または冷却するといらタイプのもの で異形のものでは図-11 の例のようである。

CIM 高速二軸連続ミキサー系造粒形のフトーシート を図-12 に示す。

次にェクストルダーの技術動向として，NC 化であ
る。自動制御技術の発達で一例として Hunker Lab. Inc. の Adaptive Ram Programmer System (ARPS) ${ }^{19}$ ) のがある。これは射出成形機用であるが，原理は混ねり に応用出来る。ARPS はキャビテー圧制御，射出速度制 御, 射出量制御の機構が独立にセットされる。図-13は 射出量制御機構である。他社からキャビテー圧力センサ ーが売り出されている ${ }^{20)} 。$

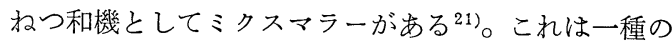
石らすの機能をそなえるものであるが，それよりもずっ と混ねり能力がある。ミクスマラーは混ねり，スミアリ ング，スパチュレートの機能をそなえたものと説明され ている。圈-14 に示す。 


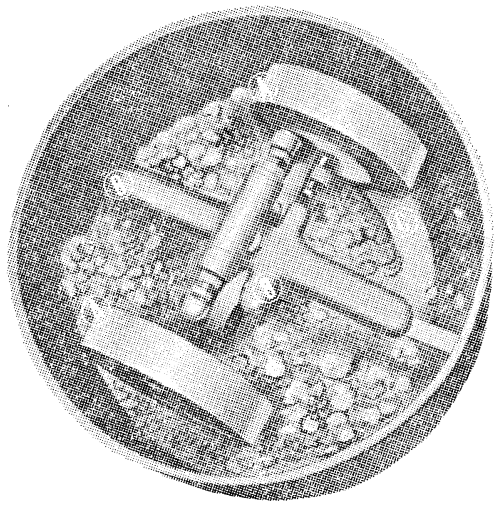

圈-14ミックスマラー21) (新東シンプソンミック スマラーによる実際のマリング作用, (A) マ ラーホイール, (B) プロー, (C) 軌跡)

その他，バンパリミキサーやバクミル等があるが省略 する。

\section{4. カクハン機型—HSD 等}

混合と混練と練合分散の区別をはっきり分離すること がむずかしいが，この種分散技術あるいはカクハン混合 技術の特長である。従って各種混合機, ミキサー類が色 材製造の際登場してくるが，この単位操作はあくまで, プロセスフローシートのセクションとしてのカクハン混 合である。

ところが化学工学で扱らカクハン混合は, 単位操作と してのカクハン混合も練合分散もねつ和も一ぱ一からげ で取り扱っている。ここで取り上げたカクハン機型とい うのは練合分散機能をもったミキサーと考えることにな る。端的にいえば, ロールミルもサンドミルも用いず に，所望の分散系を製造することが可能かどらかの問題 である。

結論として，チタン白や黄鉛のような易分散性顔料な らば，最も適切なフォミュラを用いると可能であり，現 に製造現場で採用されている。いわゆる HSD (high speed disperser) とよばれる一群のミキサーである。固 /液分散系の練合分（分散粒子が律速支配である場合） の面から取り上げると HSD でよいかもしれないが，一 般にカクハン混合操作に㓡いて課題として提出されてい る事項は次の二つである。

(1) 合成反応に拈いて，粘度上昇に伴い，終局には高 粘度となる系のカクハン混合。

(2) 超高粘稠系のカクハン混合。

両者とも色材工策において，(1)はたとえば合成樹脂の 製造の際，(2)はたとえばフラッシュベースの混合であ
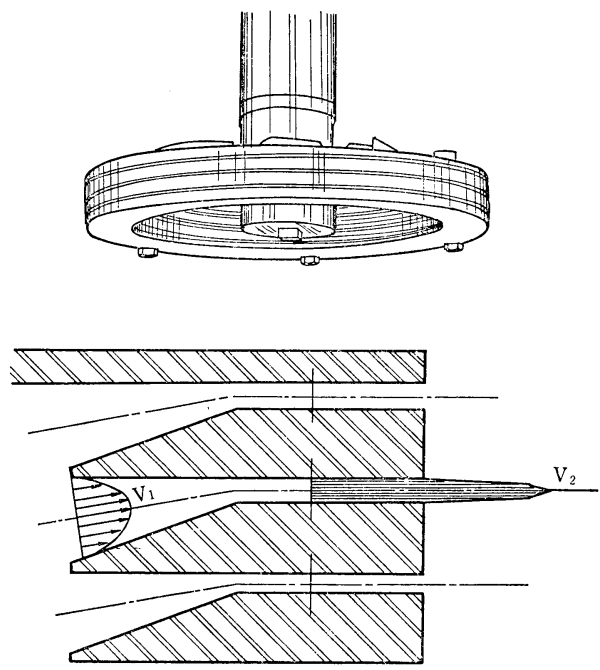

図-15 定ずりインペラー

る。

そこで, 本論は HSD のインペラーと高粘度系のカク ハンについて考えてみよう。

HSD のインペラーには sawtooth type, modified sawtooth type, multi-ring impeller, constant-shear impeller (CSI) があるが，もともとこの種のインペラ 一の分散機構は patton 流 ${ }^{22)}$ の考方方と, Daniel 流 ${ }^{23)}$ 考え方がある。Patton 流の考方方は槽内部の流線 パタ ーンよりせんだん強さを分散のファクターとすることで ある。Daniel 流の考方方はインペラーの構造とその作 用をとらえていく方法である。槽内部の流線パターン は，インペラーの直径をфとすると普通タンク径は 2.5 $\sim 4 \phi$, 液の高さは $2.5 \sim 4 \mathrm{D}$, インペラーの底よりの高 さは液の深さに対し $1 / 4 \sim 1 / 3(\min .1 / 2 \phi, \max 4 / 3 \phi$ ) の間で r. p. m, 液の粘度, 顔料の䟴度によって色々変 るので，せんだん作用領域もそれにもとついて变るので ある。従って，シャフトの位置をずらしたりすると乱流 による循環流が主流を占め, せんだんはわずかしか寄与 しない。槽内の流線パターンはパドル型を用いても， saw tooth 型を用いてもプロペラ型を用いてもほとんど 変らない。すなわら系の粘度によって, シャフト近傍に votex が生ずる現象である。

循環流は votex にすいこまれるようにインペラーの ところまでくるが，そこで強力な分散エネルギーが消費 されると，分散が可能になるわけである。

この循環を繰返し行ならわけであるから，インペラー 作用時間と循環時間がかなり重要な因子にもなる。

HSD の分散機構をDaniel は wetting — dispersing 

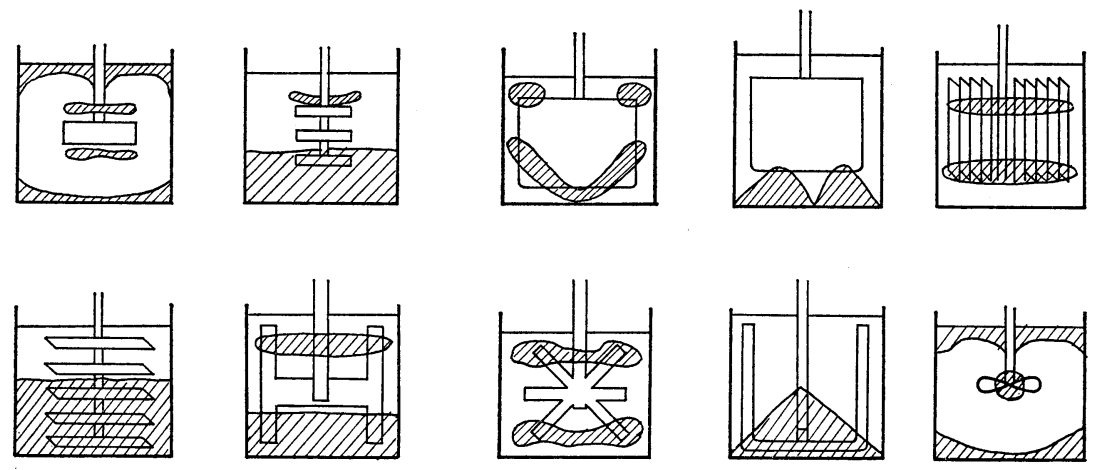

図-16 種々な翼を用いた場合の混合域 ${ }^{24)}$ (斜線の部分)

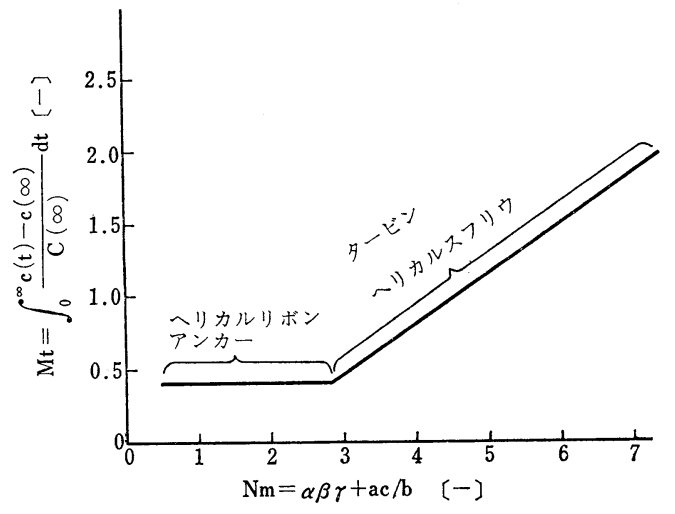

図-17 混合特性と循環時間特性 ${ }^{25)}$

$\longrightarrow$ circulation に分け考学て拉り，インペラーの機能 は, せんだん, 衝げき, 圧力の三つの要素について考兄 ている。上の分散機構の判断を vortex の状態で行うと いらことである。そして，インペラーの機能は高衝げ き，および attrition と，中程度の圧力が主な因子で粘 性流動によるせんだんは少ないとみている。Daniel は こういう考光方から sawtooth タイプよりも multir-ing タイプ multi-ring タイプよりも CSI タイプのインペ ラーへとせんだんに重点を置いたインペラーに関心を移 している。摩耗の点に掠いても, 他の二者に比べ少ない し, 特に低粘度分散系については推賞している。CSI と いうのは図-15 に示すように venturi tube の原理にも とづいている。

ただ，その間隙が $1 \mathrm{~mm}$ 程度であるので，原理的には それ以下の粒径のものなら全て可能なわけであるが，こ の間吵だと $30 〜 50$ ポイズ, $2.5 \mathrm{~mm}$ ならば 80〜100 ポ イズというように, 粘度によって変光なければならな い。もし $1 \mathrm{~mm}$ の間隙で 80 ポイズのものを分散しよう とすると，かなりの温度上昇になるにるかかわらず，あ まり分散度はよくないと思われる。
CSI を用いて 2 5t タンクの内容物を分散する場合, 温度の上昇むかなりあることに注意しなければならな い。

次に高粘度系の混合について述べたい24)。

高粘性分散系の混合で問題になる点は

(1) 構内に図のような dead space を生ずること。

(2) 混合に時間がかかること。

(3) 非ニュートン流等の場合の混合時間。

(4) 高粘性分散系を低粘度液体でうすめること。

これらの点でやはり最も重要なことは110 dead space であろら。次の図-16をみていただきたい。これら一般 的なパドル, プロペラ, ダート等のいずれのインペラー を用いても dead space が残る。そのために改良された カクハン混合機は色々の種類があるが, 水めめを水にと かした高粘性液を用いて混合特性をしらべたところ， 図-17 のようにへリカルリボン型とアンカー型がよいこ とが分った

印刷インキ関係ではへリカルリボン型はあすり聞かな いが，アンカー型は用いられているようである。たと兄 ばI社のバタフライミキサーである。

カクハン混合の特数は何をとるかという問題がある図 の縦軸は液体をこまかく細分して, 素子と考えた場合こ の素子がかきまぜで, ある点からこの点まで一循環する 時間の分布を測定し, そのときの頻度と時間の関係を数 式で表わすと

$$
\begin{aligned}
& Y_{1}(t)=\beta(t-\gamma) \sin (\pi(t-\gamma) / \alpha) \\
& Y_{2}(t)=a(t-c) \exp (-b(t-c))
\end{aligned}
$$

になるといわれる。この常数 $\alpha, \beta, \gamma, a, c, b$ を計算し

$$
N_{m}=\alpha \beta \gamma+a c / b
$$

と濃度分布を示す指数 $M_{i}$

$$
M_{i}=\int_{0}^{\infty} \frac{C(t)-C(\infty)}{C(\infty)} d t
$$

との関係をとったものである ${ }^{25) 。 ~}$ 
高粘性分散系のもら一つの特性として，このような混 合特性と循環時間特性できまることも念頭に入れて敃き たい。

な㸱化学工学では動力特性も議論されるし, 反応量で は伝熱系としての特数が入ることに注意したい。

\section{む す び}

最近の混ねり，分散機を横観したのであるが，混ね り，分散技術は二つの目的があるように思う。その一つ は研究，技術部門にお打るテスト機による混祆り分散で あり，もら一つは企業の運命を左右する現場製造技術で ある。前者も詳細にみると，分散技術によって，分散系 の性質が左右されるような場合, 消費した分散エネルギ 一や温度等によって变りらるであろらし，その目的を十 分は握して扔かなくてはならないであろう。後者はいう までもなく，out put と quality のバランスをどうする かの問題にあるから，少しでも性能のよいものへの要望 が強まるのは当然である。両者共混ねり, 分散機の新規 性を追究するのは “分散”という，きわめて深奥な領域 までまだかなりの道のりがあるということにかかわり合 っているのかもしれない。

\section{文献}

1）梅屋：“粉体”理論と応用（中川，久保，早川, 水渡編), p. 501, 丸善 (1962)

2）小石，釣谷：“分散技術入門”, 日刊工業新聞社 (1977)

3) Firma Willy A.Bachofen Maschinenfabrik 社力 タログ，特告昭 1972.9.27，No. 1290307

4） Netzsch 社カタログ（1976）
5) Draiswerke GMBH 社カタログ（1976）

6）井上製作所カタログ（1977）

7）師直：化学工場, 21 (8), 53（1977）

8) Netzsch 社カタログ（1976）

9) Netzsch 社, information (W. Sohn) (1977)

10) R. F. Conley : J. Paint Technology, 44 (567), 67 (1972)

11）たと光ば武林，小石，野呂：色材，49(12)，693 (1976)

12）化学工学協会編：“化学工学便覧”, 丸善 (1968)

13）栗本鉄工所カタログ

14）伊藤訳，J.M.McKelrey:“高分子加工工学”，丸善 (1965)

15）村上：日本綫維機械学会誌，4，126（1951） J. F. Carley et al.: Ind. Eng. Chem., 45, 967 (1953)

森, 乙升, 五十嵐 : 化学工学, 18, 221 (1954)

W. D. Mohr, C. H. Jepson, R. L. Saxton : Ind.

Eng. Chem., 49, 1855 (1957)

伊藤, 梶内：化学工学, 37(6), 581 (1973)

伊藤, 梶内：化学工学, 38(2), 138 (1974)

プラスチック加工技術便覧, 日刊工業新聞社 (1970)

16）高田：化学工場, 21(8), 48（1977）

17) Werner \& Pfleiderer Engineers 社カタログ

18）沢田：工業材料, 21(11), 98 (1973)

19) Hunkar Lab., Inc., カタログ

20）（株）サンライト“PACOM”カタログ

21）新東工業カタログ

22) T.C. Patton : J.Paint Technology, 42, 626 (1970)

23) F. K. Daniel : J. O.C.C. A., 54, 84 (1971)

24）山口：“混合抒よび擋找“，化学工業社（1973） 森：色材, 47 (8), 344 (1974)

25）引削, 大島 : 化学工学, 34, 439（1970） 